\title{
TECHNICAL EFFICIENCY ANALYSIS OF SUGAR CANE FARMING IN EAST JAVA INDONESIA (Statistical Approach of Frontier Production Functions)
}

\author{
Ika Purnamasari ${ }^{1 *}$, Nuhfil Hanani $\mathrm{AR}^{2}$, Suhartini ${ }^{2}$ \\ ${ }^{1}$ Master's Degree, Agricultural Economics, University of Brawijaya, Indonesia \\ ${ }^{2}$ Lecturer, Agricultural Economics, University of Brawijaya, Indonesia \\ *Corresponding author: ikapurnama43@gmail.com
}

\begin{abstract}
These research goals are to analyze the factors that affect the production of sugarcane, to analyze the level of technical efficiency of farming sugarcane, and to analyze the factors that technical inefficiency affecting sugarcane farming in the dry land and irrigated land. Methods of data analysis that is used to find out the factors that affect the production of sugarcane and the level of technical efficiency of sugarcane farming is a stochastic production frontier. In order to find the factors that affect technical inefficiency of sugarcane efficiency, Tobit analysis is applied. The results show that the influential factors towards the production of sugarcane in the moor land i.e. number of seedlings and the number of labor, while sugarcane production in the irrigated land are the amount of labor, urea fertilizer, ponska fertilizer and herbicides. The average technical efficiency of sugarcane farming achieved in the moor land is 0.887 and the average technical efficiency of irrigated land is 0.928 . Factors that influence technical inefficiency of sugarcane farming in the dry land are rejuvenation of sugarcane (keprasan), frequency of counseling, and seeds. While the factors for irrigated land are rejuvenation of sugarcane (keprasan) and frequency of counseling.
\end{abstract}

Keywords: Frontier production function, sugarcane, technical efficiency

\section{INTRODUCTION}

Sugarcane is a raw material that is one of the leading commodities and is very essential in the construction of sub sectors including plantations to meet the needs of domestic and export commodity as the foreign exchange earner of the country. The position of sugar as the main sweetener ingredients in Indonesia still has yet to be replaced by other materials used by households as well as the food and beverage industry. But in fact the demand for sugar was higher than the national sugar production reached. The Ministry of industry estimates of national sugar needs in 2017 will reach 5.7 million tons, whereas for sugar production reached according to the Central Bureau of Statistics (2016) is 2.3 million tons so that it was still deficit for about 3.4 million tons. This is because sugarcane plantation that became raw materials in Indonesia still faces various obstacles ranging from capital productivity, fertilizer, availability of agricultural land for a sugarcane cultivation.

One of the critical issues faced in an effort to increase production of sugarcane is the wetlandsonto increasingly narrow. Therefore there is no other choice for the sugar industry in addition for an attempting to manage and to improve the productivity of sugarcane in a dry land (Ismail and Saputro, 1990). The cultivation of sugarcane in a dry land is a very promising option to speed up the process of the achievement of quantity, quality and continuity of the production of national sugar selfreliance. The productivity of sugarcane of dry land is not even worse than the paddy fields of sugarcane famring if seeds and water supply according to the time and space can be done well. The critical point of dry land sugarcane management i.e. drought conditions which will impact against a decline in the production of sugarcane per hectare, mainly on phase of sugar 
formation as well as the maturation phase (Irianto, 2003).

An attempt to satisfy the current sugar consumption is still deficit, then it is required to increase the production of cane which is the raw material of the sugar. Efforts to increase the production of sugarcane can be done by using seeds, carry out a good cultivation techniques, the expansion area, revitalize existing sugar company, reactivate a sugar company that still had a high economic value, and build new sugar company (Manggabarani, 2008), especially in the center areas of sugarcane production in Indonesia.

Mojokerto is one of the largest sugarcaneproducing centers in East Java. The productivity of cane in Mojokerto during 2014-2016 experiencing a deficit (Central Bureau of Statistics Mojokerto, 2016). The deficit in the productivity of cane crop is influenced by a variety of factors not only the type of land (paddy fields/moorland) but also the use of the means of production and the cultivation technique (Mubyarto and Daryanti, 1991).

Low sugarcane productivity can be identified as inefficiency of farming. One of the causes of the decline in the level of efficiency of sugarcane farming is the use of factors of production that are inefficient and the decision of farmers in the use of the rejuvenation of sugarcane system in the cultivation of sugarcane (Hermanto, 2012 in Lestari, 2015). Sugarcane farming development strategy should be accompanied by efforts improved productivity, namely through increased technical efficiency of cane farmer, or in other words how to increase maximum output through resource management and existing technologies. Therefore, the analysis of technical efficiency of sugarcane farming in the moorland and paddy fields in Mojokerto seemed need to be examined.

Based on the above problems, this study aimed to: (1) Analyze the factors affecting cane production in the moorland and paddy fields (2) Analyze the technical efficiency level of cane farming in the moorland and paddy fields (3) Analyze the factors that technical inefficiency affecting sugarcane farming in the moorland and paddy fields

\section{RESEARCH METHODS}

This research was conducted in Mojokerto as one of sugarcane production center in East Java. This research was conducted during February-April 2017. Sampling techniques used simple random sampling. The number of samples taken using the formula of Slovin. The calculation result was obtained by the sample value of moorland farmer as many as 50 people and paddy fields farmer as many as 35 people.

The first methods of analysis used in the study is the analysis of stochastic frontier production function or the SFPF (Stochastic Frontier Production Function). Production frontier model allegedly using MLE (Maximum Likelihood Estimation) using the computing frontier program version 4.1. Factors that affect cane production on suspected farming in the moorland and paddy fields in Mojokerto i.e. germ, the labor, the amount of urea fertilizer, ZA, ponska, and herbicides. From the variables of the model estimating equation of functions of production frontier of the sugarcane farmer in the moorland and the paddy fields can be written as follows:

$$
\begin{aligned}
\operatorname{Ln} Y= & \beta_{0}+\beta_{1} \operatorname{Ln} x_{1}+\beta_{2} \operatorname{Ln} x_{2}+\beta_{3} \operatorname{Ln} x_{3}+ \\
& \beta_{4} \operatorname{Ln} x_{4}+\beta_{5} \operatorname{Ln} x_{5}+\beta_{6} \operatorname{Ln} x_{6}+\left(v_{i}-u_{i}\right)
\end{aligned}
$$

Where:

$\mathrm{Y}$ : sugarcane product $(\mathrm{kw})$

$\beta_{0}:$ Intercept

$\beta_{i}$ : Estimated coefficients parameters

$x_{1}$ : the amount of seed (kw)

$x_{2}$ : The amount of labor (HOK)

$x_{3}$ : the amount of Urea fertilizer $(\mathrm{kw})$

$x_{4}:$ the amount of ZA (kw)

$x_{5}$ : the amount of Phonska (kw)

$x_{6}$ : the amount of Herbisida (liter)

$u_{i}$ : Random Variable

$v_{i}:$ the effect of technical inefficiency on the model

The technical efficiency of sugarcane farming is assumed by using the equation which is formulated as follows:

$$
T E=\frac{Y}{Y^{\prime}}=\exp \left(-u_{i}\right)
$$

Where:

$$
\begin{aligned}
& \text { TE }=\text { Technical Efficiency } \\
& Y=\text { actual production } \\
& Y^{\prime}=\text { Potential Production } \\
& \text { Exp }\left(-\mathrm{u}_{\mathrm{i}}\right)=(\text { mean }) \text { ofUI } / \text { inefficiency of } \\
& \text { technique on the model } \\
& 0<\mathrm{TE} i<1
\end{aligned}
$$

The third method of analysis in this study was the tobit regression analysis to find out the factors that affect the level of technical inefficiency of farming sugarcane on the moorland and paddy 
fields in Mojokerto. The equation can be formulated as follows:

$$
\begin{aligned}
T E= & \alpha_{0}+\alpha_{1} d_{1}+\alpha_{2} d_{2}+\alpha_{3} d_{3}+\alpha_{4} d_{4}+\alpha_{5} d_{5} \\
& +\alpha_{6} d_{6}+\alpha_{7} d_{7}+\alpha_{8} d_{8}+u_{i}
\end{aligned}
$$

Where:

TE : technical inefficiency

$\mathrm{d}_{1}-\mathrm{d}_{8} \quad$ : parameters that the value was assumed through the estimator model

$\alpha_{0} \quad$ : intercept

$\mathrm{d}_{1} \quad$ : age (tahun)

$\mathrm{d}_{2} \quad$ : education (tahun)

$\mathrm{d}_{3} \quad$ : dummy of ratooncane (keprasan)

$\mathrm{d}_{3}=1$ (ratooncane 1-3) and

$\mathrm{d}_{3}=0$ (ratooncane $>3$ )

$\mathrm{d}_{4} \quad$ : counseling frequencies (times)

$\mathrm{d}_{5} \quad$ : dummy of seeds type

$\mathrm{d}_{5}=1$ (superior) and $\mathrm{d}_{5}=0$ (inferior)

$\mathrm{d}_{6} \quad$ : dummy of land tenure

$\mathrm{d}_{6}=1$ (proprietary) and $\mathrm{d}_{6}=0$ (rent)

$\mathrm{d}_{7} \quad$ : dummy of farmer's group membership

$\mathrm{d}_{7}=1$ (farmer's group) and

$\mathrm{d}_{7}=0$ (others)

$\mathrm{d}_{8} \quad$ : number of family member (person)

$\mathrm{u} \quad$ : standard error

\section{RESULTS AND DISCUSSION}

Stochastic Frontier Production Function

Analysis

a. Factors Affecting Cane Production in the Moorland

The result of estimation of stochastic frontier production function with MLE (Maximum Likelihood Estimation) in moor land can be seen in Table 1.

Table 1. The result of estimation of stochastic frontier production function in the

\begin{tabular}{|c|c|c|c|c|}
\hline \multirow{2}{*}{ Variable } & \multirow{2}{*}{ Parameter } & \multicolumn{3}{|c|}{$\begin{array}{c}\text { MLE (Maximum Likelihood } \\
\text { Estimation) }\end{array}$} \\
\hline & & coefficient & $\begin{array}{c}\text { Error } \\
\text { Standard }\end{array}$ & t-Stat \\
\hline Intercept & $\beta_{0}$ & 3,6058 & 0,8351 & $4,3178 * * *$ \\
\hline Seeds & $\beta_{1}$ & 0,4139 & 0,1208 & $3,4264 * * *$ \\
\hline Labor & $\beta_{2}$ & 0,3018 & 0,1138 & $2,6530 * * *$ \\
\hline Urea & $\beta_{3}$ & $-0,0048$ & 0,0039 & 1,2298 \\
\hline $\mathrm{ZA}$ & $\beta_{4}$ & $-0,1156$ & 0,1283 & 0,9016 \\
\hline Phonska & $\beta_{5}$ & 0,0861 & 0,1259 & 0,6836 \\
\hline Herbicide & $\beta_{6}$ & $-0,0009$ & 0,0054 & 0,1644 \\
\hline Sigma & $\sigma^{2}$ & 0,0267 & 0,0090 & $2,9708 * * *$ \\
\hline Squared & & & & \\
\hline Gamma & $\gamma$ & 0,9008 & 0,1146 & $7,8595 * * *$ \\
\hline \multicolumn{5}{|c|}{ LR test $=2,4051$} \\
\hline \multicolumn{5}{|c|}{ Note $: * * *=$ significant on 0,$01 ; * *=$ significant on 0,05} \\
\hline
\end{tabular}
moorland

Source : Primary Data, 2017 (re-make)
The results of the analysis of the retrieved value sigma-square $(\sigma)$ of 0.0267 on $99 \%$ confidence interval. Values $(\sigma)$ that is greater than zero indicates that there is an influence of technical inefficiency in the model. This is in accordance with the literature that mentions that if the value of $\sigma=0$ then there is no influence of technical inefficiency (Efani, 2010 in Asmara, et.al, 2011). The value of gamma $(\gamma)$ gained 0.90 at $99 \%$ confidence interval. The value of gamma $(\gamma)$ showed that the variation of the value of the composite error (error) is caused by the high technical inefficiency component that is $90 \%$. This is in accordance with the opinion of Coelli et al. (1998), which mentions the value $(\gamma)$ showed that the variation of the value of the composite error (error) is caused by technical inefficiency component.

Based on variables that were thought to affect the production of sugarcane in the Moor, there are two variables that are real influence variables, namely the number of seedlings and labor. Factors of production seeds has a positive coefficient of 0.41 . This indicates that the addition of seed production factor of $1 \%$ will increase production of $0.41 \%$ with other factors of production are considered fixed (cateris paribus). This is because there are still many farmers respondents who do not follow the suggestion of extension officers in the use of quantities of sugarcane seeds, where the suggestion of the use of the amount of seed that is 70-80 kw/ha under the recommended amount by extension officers. The labor of production has a positive coefficient value of 0.30 . This indicates that the addition of labor production factor of $1 \%$ will increase production of $0.30 \%$ with other factors of production are considered fixed (cateris paribus). This is due to what research there is still difficulty in terms of acquiring manpower, both in the planting, processing and harvesting season, so farmers are still not able to maximize the use of labor.

\section{b. Factors Affecting Cane Production on Paddy Field}

Estimation of stochastic frontier production function using MLE (Maximum Likelihood Estimation) in paddy field/ wetland can be seen in Table 2.

The results of the analysis of the retrieved value sigma-square $(\sigma)$ of 0.0087 , values $(\sigma)$ that is greater than zero indicates that there is an influence of technical inefficiency in the model. This is in 
accordance with the literature that mentions that if the value of $\sigma=0$ then there is no influence of technical inefficiency (Efani, 2010 in Asmara, et.al, 2011). The value of gamma $(\gamma)$ gained 0.98 , indicating that variation of the value of the composite error (error) is caused by the high technical inefficiency component i.e. amounted to $98 \%$.

Table 2. Result of frontier stochastic production function estimation of sugarcane on the paddy field

\begin{tabular}{|c|c|c|c|c|}
\hline \multirow{3}{*}{ Variable } & \multirow{3}{*}{ Parameter } & \multicolumn{3}{|c|}{$\begin{array}{l}\text { MLE (Maximum Likelihood } \\
\text { Estimation) }\end{array}$} \\
\hline & & \multirow[b]{2}{*}{$\begin{array}{l}\text { Coeff } \\
\text { icient }\end{array}$} & Err & \multirow[b]{2}{*}{ t-Stat } \\
\hline & & & $\begin{array}{c}\text { or } \\
\text { Standard }\end{array}$ & \\
\hline Intercept & $\beta_{0}$ & 5,8537 & 0,3004 & $19,4874 * * *$ \\
\hline seedlings & $\beta_{1}$ & 0,0686 & 0,0678 & 1,0124 \\
\hline Labor & $\beta_{2}$ & 0,1935 & 0,0661 & $2,9277 * * *$ \\
\hline Urea & $\beta_{3}$ & 0,0075 & 0,0029 & $3,4534 * * *$ \\
\hline $\mathrm{ZA}$ & $\beta_{4}$ & 0,0724 & 0,0871 & 0,8313 \\
\hline Phonska & $\beta_{5}$ & $-0,1647$ & 0,0419 & $3,9326 * * *$ \\
\hline Herbicide & $\beta_{6}$ & 0,0022 & 0,0008 & $2,2744 * *$ \\
\hline Sigma & $\sigma^{2}$ & 0,0087 & 0,0026 & $3,4223 * * *$ \\
\hline Squared & & & & \\
\hline Gamma & $\gamma$ & 0,9857 & 0,0793 & $12,4307 * * *$ \\
\hline- & & & & \\
\hline
\end{tabular}

Source :Primary Data, 2017 (re-make)

This is in accordance to Coelli et al. (1998), which mentions the value $(\gamma)$ showed that the variation of the value of the composite error (error) is caused by technical inefficiency component.

Based on six variables that are allegedly affect the production of cane in the paddy fields there are four variables that really influence variables, included the amount of labor, urea, phonska and herbicides. The labor has a positive coefficient of 0.19 . It shows that the addition of labor production factor of $1 \%$ will increase production of $0.19 \%$ with other factors of production is considered fixed. This is due to what research there is still difficulty in terms of acquiring manpower, both in the planting, processing and harvesting season, so farmers are still not able to maximize the use of labor. The production of urea fertilizer factor has a positive coefficient value of 0.01 this indicates that the addition of urea production factor of $1 \%$ will increase production of $0.01 \%$ with other factors of production is considered fixed. Ponska fertilizer in the production factors has a negative coefficient value of 0.16 . It is shown that the addition of fertiliser production factor of phonska $1 \%$ will lose production of $0.16 \%$ with other factors of production considered fixed (cateris paribus).

The suggestion of counseling officers to use fertilizer dose of ponska is $5 \mathrm{Kw} / \mathrm{Ha}$, but in fact the results from the analysis of the average fertilizer use ponska is $5.16 \mathrm{Kw} / \mathrm{ha}$, which means the use of fertilizer ponska exceed the suggestion extension officers and it must be reduced. The herbicides have a positive coefficient value of 0.002 this indicates that the addition of herbicide production factor of $1 \%$ will increase production of $0.002 \%$ with other factors of production is considered fixed.

\section{Technical Efficiency Analysis}

\section{a. Technical efficiency analysis of sugarcane farming on the moorland}

Table 3. The result of technical efficiency analysis of sugarcane farming in the moorland

\begin{tabular}{ccc}
\hline $\begin{array}{c}\text { Technical Efficiency } \\
\text { Level }\end{array}$ & $\begin{array}{c}\text { Farmers } \\
\text { (persons) }\end{array}$ & Precentage (\%) \\
\hline$\leq 0,799$ & 6 & 24 \\
$0,800-0,900$ & 20 & 40 \\
$\geq 0,901$ & 24 & 48 \\
Total & 50 & 100 \\
\hline Minimum $=0,695$ & & \\
Maximum $=0,977$ & & \\
Average $=0,887$ & & \\
\hline
\end{tabular}

Source: Primary Data, 2017 (re-make)

Level of technical efficiency achieved by sugarcane farmers on the moorland is 0.695 to 0.977. With the largest proportion in the Group's level of efficiency $\geq 0.901$ is $48 \%$. The number of respondents at a rate efficiency of $0.900-0.800$ is the second largest amount with a proportion of $40 \%$.

Average of the sugar farming technical efficiency in the moorland is 0.88 . This shows that the average production of sugarcane is technically already good but it can still be improved about $12 \%$ to achieve maximum efficiency. The achievement of the highest technical efficiency (maximum) is 0.977 . Moreover, the lowest technical efficiency is 0.695. The table also shows that the respondents have not yet reached the level of farmer efficiency technically, because the efficiency is still less than 0.80 . This lower efficiency value indicates the ability of farmers in practicing sugarcane production optimally. The other possible factor can be some other uncontrollable factors affecting the sugarcane production, such as weather. 


\section{b. Analysis of technical efficiency of sugarcane farming in paddy field}

Level of technical efficiency achieved by farmers' respondent sugarcane in the paddy fields is 0.836 to 0.994. Of the 35 respondents, there was no farmer who has a level of efficiency less than 0.799. All respondents are categorized efficient technically with an appropriate borderline efficiently described by (Coelli et al., 1998).

Table 4. The result of technical efficiency of sugarcane farming in the paddy field

\begin{tabular}{ccc}
\hline $\begin{array}{c}\text { Technical Efficiency } \\
\text { Level }\end{array}$ & $\begin{array}{c}\text { Farmers } \\
\text { (Persons) }\end{array}$ & $\begin{array}{c}\text { Precentage } \\
(\%)\end{array}$ \\
\hline$\leq 0,799$ & 0 & 0 \\
$0,800-0,900$ & 10 & 28,57 \\
$\geq 0,901$ & 25 & 71,43 \\
Total & 35 & 100 \\
\hline
\end{tabular}

Minimum $=0,836$

Maximum $=0,994$

Average $=0,928$

Source : Primary Data, 2017 (re-make)

Based on Table 4, the level of efficiency attained by respondents with the largest proportion in the Group's level of efficiency $\geq 0.901$ i.e as much as $71.43 \%$. The rest of $28.57 \%$ respondents at a rate of efficiency $0.90-0.80$. The average level of technical efficiency of sugarcane farming in paddy fields is 0.93 . The average value of these high technical efficiency shows that the average of cane production in the paddy fields is technically already good but can still be improved again amounted to $7 \%$ to achieve the optimal level of technical efficiency.

\section{Technical Inefficiency Analysis}

\section{a. Factors Influencing the Technical Inefficiency of Sugarcane Farming in Moorland}

The results of the analysis using the confidence level of $99 \%$ and $95 \%$ indicated that the factors that really influence against technical inefficiency of sugarcane farming is dummy of rejuvenation of sugarcane ratoon cane (keprasan), frequency of counselling, and dummy types of seeds. All coefficients have a negative sign. The negative sign indicates that the addition of these inputs causes the reduction effect of inefficiency on a cane farming.
Table 5. The regression analysis results of factors affecting inefficiency of sugarcane farming in the moor land

\begin{tabular}{lcccc}
\hline \multicolumn{1}{c}{ Variable } & Coefficient & $\begin{array}{c}\text { Std. } \\
\text { Error }\end{array}$ & z-Statistic & Prob. \\
\hline C & 0.187650 & 0.064585 & 2.905489 & 0.0037 \\
Age & -0.000005 & 0.000788 & -0.005760 & 0.9954 \\
$\begin{array}{l}\text { Education } \\
\text { Dummy of } \\
\text { ratooncane }\end{array}$ & 0.003761 & 0.002908 & 1.293485 & 0.1958 \\
$\begin{array}{l}\text { Counseling } \\
\text { frequencies }\end{array}$ & -0.043240 & 0.017422 & -2.481939 & $0.0131^{* *}$ \\
$\begin{array}{l}\text { Dummy of } \\
\text { seeds }\end{array}$ & -0.055162 & 0.020284 & -2.719445 & $0.0065^{* * *}$ \\
$\begin{array}{l}\text { Dummy of } \\
\text { land }\end{array}$ & -0.018370 & 0.027728 & -0.662490 & 0.5077 \\
$\begin{array}{l}\text { ownership } \\
\text { Farmer's } \\
\text { group }\end{array}$ & 0.010850 & 0.018241 & 0.594809 & 0.5520 \\
$\begin{array}{l}\text { membership } \\
\text { JAK }\end{array}$ & -0.002771 & 0.006905 & -0.401228 & 0.6883 \\
\hline \multicolumn{1}{c}{ Source : Primary Data, 2017 (re-make) } & \\
\hline
\end{tabular}

The results of the analysis show that, ratoon sugarcane is a significant influential factor affect the sugarcane farming technical inefficiency in the moorland. The value of the ratoon sugarcane coefficient is 0.04 and negative. That value indicates that farmers who planted cane with fewer ratoon sugarcane frequency will result a lower level of inefficiency.

Still plenty of farmers do ratoon sugarcane more than three times. Counseling variables significantly affect technical inefficiency of farming sugarcane in the moorland with coefficients i.e. 0.02 and negative. These values indicate that the farmers who receive more counselling frequency may decrease the effect of technical inefficiency. This also means that the existence of the agricultural counseling officers making the farmers can be educated in sugarcane cultivation optimally. Seedling significantly affects technical inefficiency of cane farming in the moorland with coefficients i.e. 0.06 and negative. These values indicate that the use of the seeds will get the lower level of technical inefficiency of $0.06 \%$. The fact is that, there are still many farmers using local seeds from their crops of sugarcane. The reason behind this is because the farmers want to save additional cost by using local seeds.

\section{b. Factors affecting technical inefficiency of cane farming in the paddy field}

The results of factors affecting technical inefficiency of sugarcane farming in the paddy field can be seen in Tabel 7. The results of the analysis showed that the factors which effect 
significantly against technical inefficiency of sugarcane farming in the paddy fields i.e. Dummy of ratoon sugarcane and counseling frequency. Both the inefficiency factors are negative. The coefficient of ratoon sugarcane is 0.08 and negative. That value indicates that farmers who planted sugarcane with fewer ratoon frequency will result in a lower level of inefficiency. Moreover, the coefficient for counseling is 0.13 and the sign is negative. That value indicates that farmers who receive counseling will be more frequently decrease the effect of technical inefficiency.

Table 7. The results of factors affecting technical inefficiency of cane farming in the paddy field

\begin{tabular}{|c|c|c|c|c|}
\hline Variable & Coefficient & $\begin{array}{c}\text { Std. } \\
\text { Error }\end{array}$ & $\begin{array}{c}\mathrm{z}- \\
\text { Statistic } \\
\end{array}$ & Prob. \\
\hline $\mathrm{C}$ & 0.164149 & 0.141546 & 1.159686 & 0.2462 \\
\hline Age & -0.000686 & 0.002709 & $\begin{array}{c}- \\
0.253212\end{array}$ & 0.8001 \\
\hline education & 0.004045 & 0.004192 & 0.964789 & 0.3347 \\
\hline $\begin{array}{l}\text { Dummyof } \\
\text { ratooning }\end{array}$ & -0.078605 & 0.028897 & $\begin{array}{c}- \\
2.720199\end{array}$ & $0.0065^{* * *}$ \\
\hline $\begin{array}{l}\text { Counseling } \\
\text { frequencies }\end{array}$ & -0.131288 & 0.042270 & 3.105896 & $0.0019^{* * * *}$ \\
\hline $\begin{array}{l}\text { Dummy of } \\
\text { seedlings }\end{array}$ & 0.006549 & 0.042296 & 0.154843 & 0.8769 \\
\hline $\begin{array}{l}\text { Dummy of } \\
\text { land } \\
\text { ownership }\end{array}$ & 0.025141 & 0.026406 & 0.952077 & 0.3411 \\
\hline JAK & 0.014198 & 0.015038 & 0.944141 & 0.3451 \\
\hline
\end{tabular}

Source: Primary Data, 2017 (re-make)

\section{CONCLUSIONS AND SUGGESTIONS}

\section{Conclusion}

The result of the stochastic frontier production estimation shows that there are factors positively influence towards the production of sugarcane in the moor land. They are variable number of seedlings and the number of labor. Production factors that significantly and positively influence towards the production of sugarcane in paddy fields are the amount of labor, urea fertilizers, and herbicides. Whereas, production factors that influence negatively in sugarcane production of paddy fields is the number of phonska given.

Technical efficiency estimation results showed that the production of cane in the moor land and the paddy fields have already reached a high level of efficiency. The average level of technical efficiency of sugarcane in moor land is 0.887 and the average level of technical efficiency of sugarcane in the paddy fields is 0.928 .
The results of the regression analysis showed that the factors affecting sugarcane production in the moor land technical inefficiencies are a dummy of ratoon sugarcane (keprasan), counseling frequency, and dummy of seedlings. While the factors that affect sugarcane farming technical inefficiency in the paddy fields are a dummy of ratoon cane (keprasan) and counseling frequency.

\section{Suggestions}

1. The proportion of the use of inputs (recommended used of inputs) should be informed clearly to the farmer in order to improve efficiency level. Moreover, the use of the input should be increased in the moorland. They are seed and labor. While sugarcane farming in the paddy fields, the use of inputs should be increased are labor, urea and herbicides. However, phonska should be reduced because of excessive usage.

2. Socio-economic factors that affect technical inefficiency of sugarcane production are number of ratoon sugarcane, the type of seeds and counselling frecuency. Increased efficiency of technical farming sugarcane in Mojokerto can be done through a reduction in the amount of ratoon, seeds, the use of public awareness and participation. Therefore, it is expected that the authorities should help farmers to get superior seeds and facilitate for loading the ratoon.

\section{REFERENCES}

Asmara, R., N. Hanani dan N. Irawati. 2011. Analisis Efisiensi Teknis Dengan Pendekatan Frontier Pada Usaha Pembuatan Chips Mocaf (Modified Cassava Flour). Habitat, 12 (1) : 51-59.

BPS Kabupaten Mojokerto. 2016. Kabupaten Mojokerto dalam Angka Tahun 2016. Badan Pusat Statistik. Mojokerto.

BPS Republik Indonesia. 2016. Produksi Gula Nasional 2016. Badan Pusat Statistik. Jakarta

Coelli, T.J., D.S.P. Rao., C.J. Donnell and G.E Battese. 1998. An Introduction To Efficiency And Productivity Analysis 
Second Edition. Kluwer Academic Publisher. London.

Hidayah, I., N. Hanani., R. Anindita and B. Setiawan. 2013. Production and Cost Efficiency Analysis Using Frontier Stochastic Approach, A Case on Paddy Farming System With Integrated Plant and Resource Management (IPRM) Approach In Buru District Maluku Province Indonesia. Journal of Economics and Sustainable Development, 4 (1) : 78-84.

Irianto, G. 2003. Tebu Lahan Kering dan Kemandirian Gula Nasional. Tabloid Sinar Tani.

Ismail, I.S. dan S.E. Saputro. 1990. Kajian tentang Masa Tanam dan Umur Tebang dari Dua Varietas Unggul Q 90 dan PS 61 di Tanah
Ultisol PG. Bunga Mayang. Majalah Perusahaan Gula. 26 (4) : 7-12.

Lestari, E.K. 2015. Efisiensi dan Kerangka Kelembagaan Tebu Rakyat dalam Mendukung Perekonomian Wilayah di Kabupaten Jember. Disertasi. Pascasarjana. Institut Pertanian Bogor. Bogor.

Manggabarani, A. 2008. Momentum Seabad Kebangkitan Nasional. Gula Indonesia. 12 (1) : 3-5.

Mubyarto dan Daryanti. 1991. Gula. Kajian SosialEkonomi. Aditya Media. Yogyakarta. 